\title{
Livermore laboratory buys Russian papers on laser technology
}

Washington. Lawrence Livermore National Laboratory in California is buying $\$ 300,000$ worth of unclassified research reports and hardware from 19 Russian laboratories and one Ukrainian institute in the latest example of scientists in the former Soviet Union finding novel, capitalist ways to support their research.

The research is unclassified and not related to work on weapons. It involves laser technologies with potential applications in monitoring the atmosphere for improved weather prediction and pollution control and chemical and optical technologies for breaking down hazardous wastes.

The Russian and Ukrainian scientists are expected to deliver the material within three months. Although some of the ex-Soviet scientists may be invited to Livermore to answer questions, none will do research at the US laboratory nor work jointly with their US colleagues.

"It's a straight business deal", says a spokesman for the laboratory. "We get technical material, in English, and hardware, and they get US dollars plus the professional satisfaction of knowing that their work is being put to use."

The purchase was negotiated by a four-man team that visited Russia this past summer. It is separate from an agreement among the United States, the European Communities and Japan to support international research centres in Moscow and Kiev employing former Soviet weapons scientists on projects of interest to their industrialized partners. But that initiative, scheduled to be launched during the summer, is mired in government red tape and has yet to make its first award.

It is also different from the increasingly common arrangement by which teams of Russian scientists are hired by a Western company to carry out joint research. Last month, for example, AT\&T Bell Laboratories announced a contract with the A.F. Ioffe Physico-Technical Institute in St Petersburg in which 27 Ioffe scientists will do basic research in semiconductor physics and semiconductor lasers. In February, the laboratory's material science division signed a similar contract with some 90 scientists at the General Physics Institute in Moscow.

Unlike the Livermore purchases, the contract between AT\&T and the Russian institutes provides money for salaries, equipment and travel. Although Western companies have been accused of simply hiring cheap labour, the contracts are intended to keep research teams intact in the face of declining support by the governments of Russia and the other former Soviet republics.

\section{Costs curtail but do not kill European space laboratory}

Granada, Spain. Disputes between Germany and France over their favoured man-in-space projects were patched up at last week's ministerial meeting in Granada of the European Space Agency (ESA) held to decide ESA's plans to the end of the century. But the compromises failed to resolve the fundamental issue of how to pay the bill for the prestigious space laboratory project, designed as a component of the international space station Freedom.

ESA's determination to present a united public face averted a looming crisis similar in the DM2.5 billion project from 14 per cent to 10 per cent and suggested a review of its overall cost, raising the prospect of a delay that would be unacceptable to the Germans. At the same time, Spain announced that it was cutting by half its 6 per cent contribution, leaving the project only 90 per cent funded.

Despite its strong interest, Germany refused to increase its share. As a temporary solution, the ministers agreed to continue development while ESA seeks a reduction of 5 per cent over the next three years in total

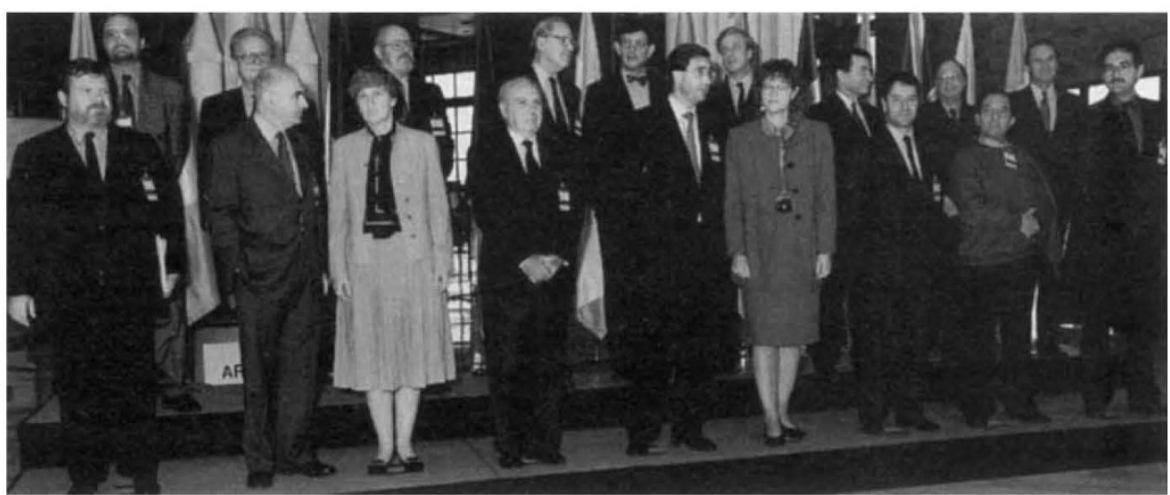

The ESA ministers may have been more friendly in public than in private.

to that at last year's meeting in Munich, when ministers from ESA's 13 members overturned long-held plans because they could no longer afford the spiralling costs. This time, ESA council members have been given a year to trim 15 per cent from their original proposals costing DM52.8 billion (US $\$ 35$ billion), but disagreement between the major players, France and Germany, continues to pose problems. Just before the meeting began, for example, the council failed to reach a consensus on funding for the space laboratory, known as the APM (attached pressurized module).

The major sticking point has been Europe's two major contributions to the international space station mission - the APM and the space plane Hermes. France's elaborate hopes for Hermes, intended to ferry astronauts to the space station, have been thwarted by German efforts to keep costs 'realistic' (see Nature 357, 351; 1992). France had agreed to pay 40 per cent of the project's costs, which under ESA rules entitles it to 40 per cent of the ensuing industrial contracts. But the project has been downgraded at best to an unmanned vehicle that may not stand on its own.

Germany had taken a similarly large stake in APM, which will be attached to Freedom as an experimental area for astronauts. Last week, France said it would reduce its stake costs. Funding for the remaining 5 per cent was left unresolved.

ESA was given until March next year to make good that shortfall. Its president, Hubert Curien, the French science minister, said that countries interested in the project will be asked to increase their stake. Italy, whose 25 per cent interest in the project makes it the second largest investor, has informally indicated its willingness to step into the breach. Spain may soften its stance if the ESA council next month agrees to adjust the general contributions from members to account for currency devaluations.

Less controversial was a decision to seek wider international cooperation, particularly in the development of space vehicles with Russia (see Nature 359, 176; 1992). The resolution also asks for "foundations to be laid for cooperation with Japan" and the "deepening" of established cooperation with the United States.

Projects for Earth observations won strong support from delegations eager to embrace environmental protection. In switching its financial interest from the APM to its associated multisatellite system, the 'polar platform', France now overtakes Britain as the major player, with an estimated 23.6 per cent share, but British Aerospace is expected to retain its position as prime contractor.

Alison Abbott 